\title{
Plasma Levels of Proinsulin, Insulin and C-peptide in Chronic Renal, Hepatic and Muscular Disorders
}

\author{
Yoshimichi Imamura, MD*, Koichi Yokono, MD, Kozui Shir, MD, \\ Joji Hari, MD, Hideyo SAkal, MD and Shigeaki BABA, MD
}

\begin{abstract}
Proinsulin, insulin and C-peptide levels were investigated in chronic renal, hepatic and muscular disorders. The proinsulin levels in human plasma were determined by radioimmunoassay using insulin-degrading enzyme (IDE). The fasting levels of proinsulin in 29 patients with chronic renal failure (0.95 \pm 0.05) were significantly higher than those in 10 patients with liver cirrhosis $(0.46 \pm 0.04)$, six with muscular dystrophy $(0.37 \pm 0.02)$ and 52 normal subjects $(0.24 \pm 0.02 \mathrm{ng} / \mathrm{ml}$, mean \pm S.E. $)$. The fasting levels of insulin and C-peptide in chronic renal failure were also the highest among these groups. The insulin levels in liver cirrhosis and muscular dystrophy were significantly greater than those in normal subjects and increased molar ratios of proinsulin to total insulin immunoreactivity in chronic renal failure were observed. These results suggest that the kidney, liver and muscle are related to circulating insulin levels and that the kidney plays a particularly important role in circulating proinsulin levels. It can be concluded that increases in these peptides are due to a hypersecretion of B-cells, a decreased degradation or excretion.
\end{abstract}

Key Words: Proinsulin, Insulin, C-peptide, Insulin-degrading enzyme, Chronic renal failure, Liver cirrhosis, Muscular dystrophy.

The discovery of proinsulin, the single chain precursor of insulin ${ }^{1)}$, has produced a great interest in its characteristics and in the insulin-processing mechanism. Although many investigators have studied proinsulin in plasma, the difficulty in measuring this material has limited the number of samples analyzed. Previously, we reported the results of purification and characterization of insulin-degrading enzyme (IDE) extracted from pig skeletal muscles ${ }^{2}$. This enzyme has a high degree of specificity for insulin and rapidly degrades the hormone, whereas proinsulin is not appreciably affected. According to the enzymatic method developed by Kitabchi et al. ${ }^{3)}$, we have also succeeded in devising a simple method of proinsulin determination in plasma.
It is well known that insulin-degrading enzymes exist in the kidney, liver, muscle and many tissues ${ }^{4,5)}$. In rats, the liver is the major organ for removal and disposal of circulating insulin $^{6,7)}$, and the kidney represents a major site for the insulin, C-peptide and proinsulin metabolisms ${ }^{8}$. These experiments suggest that the kidney, liver and muscle may play an important role in determining the circulating levels of insulin, C-peptide and proinsulin. There is particularly little information or clinical interpretation regarding the levels of plasma proinsulin.

Therefore, we investigated the levels of proinsulin, insulin and C-peptide in normal subjects and patients with chronic renal failure, liver cirrhosis and muscular dystrophy and, as a result,

From *The Cancer Center of Hyogo Prefectural Hospital, 5-3, 7-chome, Kusunoki-cho, Chuo-ku, Kobe 650, Japan, and The Second Department of Internal Medicine, Kobe University School of Medicine.

Received for publication October 22, 1983.

Reprint requests to: Shigeaki Baba, MD. The Second Department of Internal Medicine, Kobe University School of Medicine, 5-1, 7-chome, Kusunoki-cho, Chuo-ku, Kọe, 650, Japan. 
decided to study the behavior of proinsulin together with that of insulin and C-peptide, with the aim of establishing the role of hepatic and renal catabolism in hyperproinsulinemia, which is a frequent finding in liver cirrhosis and chronic renal failure.

\section{MATERIALS AND METHODS}

\section{Subjects and experimental procedures}

Plasma samples were obtained from 52 normal subjects, 29 patients with chronic renal failure without hepatic involvement, 10 with liver cirrhosis without renal involvement and six with muscular dystrophy, after an overnight fast. The six patients with muscular dystrophy had Duchenne's dystrophy without hepatic or renal involvement. All patients with chronic renal failure were treated by hemodialysis consisting of two dialysis per week for more than three years, and plasma samples were obtained before hemodialysis. No patient was overtly diabetic or obese $(<120 \%$ of ideal body weight). Fifty grams of glucose were administered orally after an overnight fast to 12 normal subjects, five patients with liver cirrhosis, six with muscular dystrophy and five with chronic renal failure. Blood samples were withdrawn at $0,30,60,90$ and 120 minutes and analyzed for glucose, immunoreactive insulin (IRI), C-peptide immunoreactivity (CPR) and immunoreactive proinsulin (IRP).

\section{Enzyme preparation}

Freshly removed pig-leg muscle was trimmed of fat and connective tissue and homogenized in $0.35 \mathrm{M}$ sucrose, $5 \mathrm{ml} / \mathrm{g}$ of tissue. The homogenate was centrifuged at $100,000 \times \mathrm{G}$ for one hour. The supernatant was partially purified by ammonium sulfate precipitation (40-70\% fraction) and Biogel p-200 column chromatography. The Biogel p-200 purified fractions were lyophilized and stored at $-80^{\circ} \mathrm{C}$.

\section{IRP assay}

The incubation mixture, consisting of $0.2 \mathrm{ml}$ of sample or standard, $0.2 \mathrm{ml}$ of $0.1 \mathrm{M}$ potassium phosphate buffer (pH 7.0) and 0.1. $\mathrm{ml}$ of IDE (1 $\mathrm{mg}$ protein), was incubated at $37^{\circ} \mathrm{C}$ for $18 \mathrm{~min}$ - utes, and the reaction was stopped by the addition of $0.1 \mathrm{ml}$ of $10 \mathrm{mM} \mathrm{N}$-ethylmaleimide. This mixture was assayed for IRP by double antibody radioimmunoassay using a modification of the method of Morgan and Lazarow ${ }^{9)}$ as follows. The mixture consisted of $0.2 \mathrm{ml}$ of sample or standard, $0.2 \mathrm{ml}$ of 1:180,000 guinea-pig antiporcine insulin serum, $0.2 \mathrm{ml}$ of $1: 200$ normal guinea-pig serum and $0.1 \mathrm{M}$ borate buffer $(\mathrm{pH}$ 8.6) containing $0.25 \%$ bovine serum albumin, to a total volume of $0.6 \mathrm{ml}$. After incubation at $4^{\circ} \mathrm{C}$ for 24 hours, $0.2 \mathrm{ml}$ of porcine ${ }^{125}$ I-insulin $(0.08 \mathrm{ng})$ was added. After an additional 24 hours of incubation, $0.2 \mathrm{ml}$ of $1: 8$ rabbit antiguinea-pig globulin serum was added, and the mixture was incubated at $4^{\circ} \mathrm{C}$ for 24 hours. After centrifugation at $3000 \mathrm{rpm}$ for 30 minutes, the supernatant was decanted and the precipitates counted. The values of IRP were determined by the use of porcine proinsulin (provided by Novo Laboratories, Ltd.) as the standard.

\section{IRI and CPR assay}

IRI was assayed before enzyme treatment with the same incubation system. The values of IRI were determined using porcine insulin (provided by Novo Laboratories Ltd.) as the standard. CPR was assayed by the double antibody radioimmunoassay method of Kaneko et al. ${ }^{10}$ ) using synthetic human C-peptide as the standard.

\section{Gel filtration}

Proinsulin and insulin were separated by a Biogel p-30 column $(0.9 \times 56 \mathrm{~cm})$ equilibrated with $3 \mathrm{M}$ acetic acid. The fraction size was 0.6 $\mathrm{ml}$, and the IRI of each fraction was measured by double antibody radioimmunoassay.

\section{RESULTS}

Based on the results that have clarified the characteristics of insulin-degrading enzyme (IDE), as shown Fig. 1, we are comprehensively considering methods of progressing with our study in the future. Namely, in the figure, the upper column demonstrates the time course of degradation of porcine insulin and proinsulin with IDE. IDE rapidly degraded high and low concentrations of insulin to non-immunoassayable components, whereas proinsulin was not appreciably degraded 

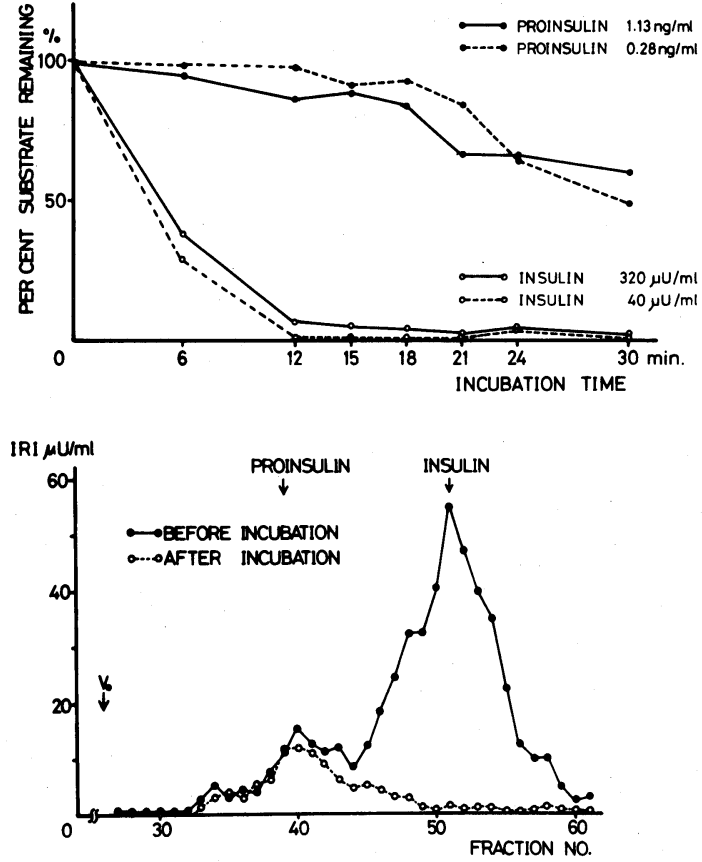

Fig. 1 The principle of the proinsulin assay using insulin-degrading enzyme (IDE). The upper column shows the time course of porcine proinsulin and insulin degradation by IDE. The lower column shows the elution pattern from a Biogel P-30 column of the sample before and after incubation with IDE. The sample contained $16.7 \mathrm{ng}$ of porcine insulin and $8 \mathrm{ng}$ of porcine proinsulin, and IRI of each fraction was determined by double antibody radioimmunoassay.

during the first 18 minutes of incubation. However, when the incubation time was extended to more than 18 minutes, the degradation of proinsulin occurred. The lower column shows the elution patterns from a Biogel p-30 column of the samples before and after incubation with IDE. The sample before incubation indicated two peaks, the first corresponding to proinsulin and the second to insulin. On the other hand, the sample after incubation indicated a single peak corresponding to proinsulin, with the insulin peak disappearing. In addition, IDE degraded human as well as porcine insulin, and serum did not interfere with this degradation.

The fasting levels of IRI, GPR and IRP are shown in Table 1. The fasting levels of IRP in 29 patients with chronic renal failure $(0.95 \pm 0.05)$
Table 1. Fasting level of IRI, CPR and IRP in normal subjects, patients with muscular dystrophy, liver cirrhosis and chronic renal failure.

${ }^{*} \mathrm{p}<0.001, * * \mathrm{p}<0.05$, compared with normal subjects.

\begin{tabular}{cccc}
\hline Groups & $\begin{array}{c}\text { IR I } \\
(\mu \mathrm{U} / \mathrm{ml})\end{array}$ & $\begin{array}{c}\text { CPR } \\
(\mathrm{ng} / \mathrm{ml})\end{array}$ & $\begin{array}{c}\text { IRP } \\
(\mathrm{ng} / \mathrm{ml})\end{array}$ \\
\hline Normal Subjects & $9.5 \pm 0.4$ & $1.9 \pm 0.1$ & $0.24 \pm 0.02$ \\
$\begin{array}{c}(n=52) \\
\text { Muscular Dystrophy } \\
(n=6)\end{array}$ & $12.5 \pm 2.1^{* *}$ & $1.8 \pm 0.2$ & $0.37 \pm 0.02^{*}$ \\
$\begin{array}{c}\text { Liver } \begin{array}{c}\text { Cirrhosis } \\
(n=10)\end{array} \\
\text { Chronic Renal Failure } \\
(n=29)\end{array}$ & $16.5 \pm 1.6^{*}$ & $3.7 \pm 0.3^{*}$ & $0.46 \pm 0.04^{*}$ \\
\hline
\end{tabular}

were significantly higher $(\mathrm{p}<0.001)$ than those in 10 patients with liver cirrhosis $(0.46 \pm 0.04)$, six with muscular dystrophy $(0.37 \pm 0.02)$ and 52 normal subjects $(0.24 \pm 0.02 \mathrm{ng} / \mathrm{ml}$, mean \pm S.E.). The IRP levels in liver cirrhosis and muscular dystrophy were markedly higher $(\mathrm{p}<0.001)$ than those in normal subjects. The CPR levels in chronic renal failure and liver cirrhosis were significantly higher $(\mathrm{p}<0.001)$ than those in muscular dystrophy and normal subjects. The IRI levels were significantly increased in chronic renal failure, liver cirrhosis and muscular dystrophy as compared with normal subjects $(\mathrm{p}<0.001$ and $\mathrm{p}<$ $0.05)$. No significant differences in the fasting blood glucose levels were observed among the four groups.

The blood glucose, plasma IRI, CPR and IRP levels in the four groups after oral glucose load are shown in Fig. 2. The three patient groups had mild glucose intolerances after oral glucose load. In comparison with normal subjects, the IRI responses in the three patient groups were greater, but these responses showed delayed patterns. When the CPR and IRP levels in chronic renal failure were compared to those in the other groups, the former had greater CPR and IRP levels at all times, and the differences were significant $(\mathrm{p}<0.001)$. Although the CPR responses in liver cirrhosis were greater than those in muscular dystrophy and normal subjects, the IRP responses in these three groups were similar.

To determine the releasing molar ratios from 

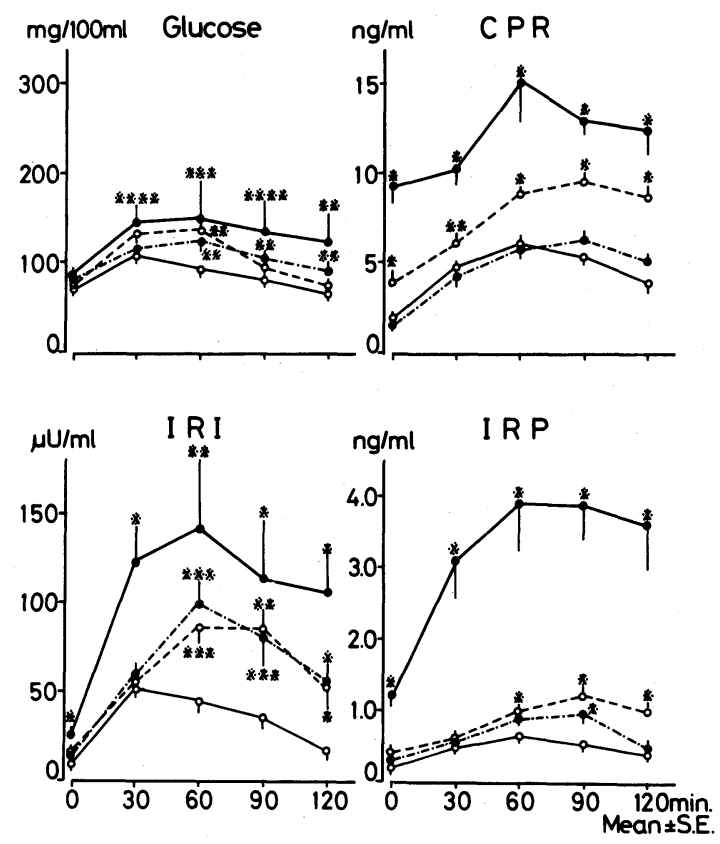

Fig. 2 Blood glucose, plasma IRI, CPR and IRP levels after the $50 \mathrm{~g} \mathrm{O-GTT.}$

o- o normal subjects $(n=12)$, o- - -0 muscular dystrophy $(n=6)$, o- $-\circ$ liver cirrhosis $(n=5), \bullet$ chronic renal failure $(n=5)$.

$* \mathrm{p}<0.001, * * \mathrm{p}<0.005, * * * \mathrm{p}<0.01, * * * * \mathrm{p}<0.05$, compared with normal subjects.

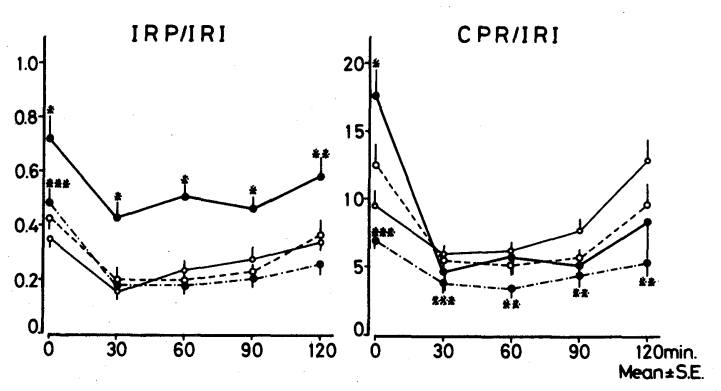

Fig. 3 The molar ratios of IRP/IRI and CPR/IRI after the $50 \mathrm{~g}$ O-GTT.

o- 0 normal subjects $(\mathrm{n}=12), \bullet-\longrightarrow$ muscular dystrophy $(n=6)$, o- -0 liver cirrhosis $(n=5), \bullet$ chronic renal failure $(n=5)$.

$* \mathrm{p}<0.001, * *_{\mathrm{p}}<0.01, * * * \mathrm{p}<0.05$, compared with normal subjects.

pancreatic B-cells, the molar ratios of IRP/IRI and CPR/IRI in these four groups were ascertained, as shown in Fig. 3. The molar ratios of
IRP/IRI in chronic renal failure were significantly higher than those in the other three groups, and there were no differences among these three groups. Although the fasting molar ratios of CPR/IRI in chronic renal failure were remarkably high, the CPR/IRI ratios after glucose load did not differ from normal subjects. On the other hand, the molar ratios of CPR/IRI in muscular dystrophy were significantly lower than those in normal subjects.

\section{DISCUSSION}

In the Golgi apparatus of pancreatic B-cells, proinsulin is cleaved into insulin and C-peptide ${ }^{11)}$, which are subsequently secreted into the portal circulation in equimolar quantities ${ }^{12}$. It is well known that the circulating insulin levels increase in patients with chronic renal failure and liver cirrhosis $^{13,14)}$. Elevated C-peptide levels ${ }^{15,16)}$ and proinsulin ${ }^{13,17)}$ were also revealed in patients with chronic renal failure. Experiments with the infusion of insulin, C-peptide and proinsulin in rats have suggested that the kidney is the main organ for the removal of circulating proinsulin and C-peptide ${ }^{8)}$.

In the present study, the fasting levels of IRI, CPR and IRP in chronic renal failure were significantly higher than those in the other groups (Table 1). These results were accordance with the findings of other studies ${ }^{13,16,17)}$. In liver cirrhosis, the C-peptide levels have been found to be normal ${ }^{14)}$, high $^{18,19)}$ or slightly elevated ${ }^{20)}$. Significant increases of IRI and IRP levels in liver cirrhosis and muscular dystrophy suggest that liver and muscle functions could be related to circulating insulin levels and slightly related to proinsulin levels. However, our data did not agree with the results of Mako et al. ${ }^{13)}$ who observed lower proinsulin levels coexisting with normal insulin concentrations in nine patients with hepatic failure. It is possible that the degree of liver damage and impaired carbohydrate tolerance are different in the two series of patients. In fact, experiments with hepatic extraction of proinsulin and insulin using isolated perfused rat liver result in low hepatic extraction of pro- 
insulin ${ }^{6)}$. Recently, Tocafondi et al. reported that plasma proinsulin-like component levels were increased in patients with liver cirrhosis ${ }^{21)}$.

Moreover, the IRP and CPR levels after glucose load were also significantly higher in chronic renal failure than those in the other groups at all times (Fig. 2). Jaspan et al. ${ }^{17)}$ also reported that the levels of proinsulin, IRI and CPR were higher in patients with chronic renal failure than in controls. Although they did not measure the proinsulin levels after glucose load, their fasting levels of proinsulin and the responses of IRI and CPR were in good agreement with our results. The CPR responses in liver cirrhosis were greater than those in muscular dystrophy and normal subjects. In this connection, there are two concepts, i.e., that the liver is related to the C-peptide metabolism ${ }^{22)}$ or is not ${ }^{6,8)}$. Although the responses of CPR and IRP in muscular dystrophy were similar to those in normal subjects, IRI responses were greater in muscular dystrophy than in normal subjects. Recently, it has been reported that, in uremic rats, insulin removal or degradation by the muscle was decreased and that by the liver was not affected $^{23,24)}$. Since our patients with muscular dystrophy had normal hepatic and renal functions, there would be no effect on the IRI and IRP levels.

It has been demonstrated that incomplete degradation of insulin is observed in serum containing less than $20 \mu \mathrm{U} / \mathrm{ml}$ of IRI by insulinspecific protease ${ }^{25)}$. In normal subjects, however, the fasting levels of IRP were $0.24 \pm 0.02 \mathrm{ng} / \mathrm{ml}$ (mean \pm S.E.), and the molar ratios of IRP/IRI were $0.35 \pm 0.03$ (mean \pm S.E.). These values were in good agreement with the results of other researchers ${ }^{26-28)}$. If the degradation of insulin is not complete, the values of IRP determined by our enzymatic method will be high. Cresto et al. reported that the proinsulin values determined by the enzymatic method were a little higher than those ascertained by gel filtration ${ }^{29)}$, and we obtained similar results (data not shown).

The molar ratios of IRP/IRI before and after glucose load were significantly higher in chronic renal failure than those in the other groups (Fig. 2). These results suggest that proinsulin may be the major component of total immunoreactive insulin in patients with chronic renal failure.

In summary, these results point to the possibility that the metabolic processes of the kidney, liver and muscle are responsible for the high blood levels of insulin, C-peptide and proinsulin seen in the chronic renal failure, liver cirrhosis and muscular dystrophy patients examined. Namely, the kidney, liver and muscle are related to the circulating insulin levels, and the liver and muscle slightly related to the circulating proinsulin levels. The kidney plays a particularly important role in the circulating proinsulin levels as well as those of C-peptide. It can be concluded that the high levels of insulin, C-peptide and proinsulin found in chronic renal failure are due not only to a hypersecretion of B-cells but also to a decreased degradation or excretion of the hormone in the kidney, while the high levels of these peptides in liver cirrhosis are due to a decreased hepatic degradation of the hormones, mainly insulin, rather than a hypersecretion of B-cells.

ACKNOWLEDGMENT: We would like to thank Dr. S. Emi, Toyobo Ltd. Co., for the enzyme preparation and his invaluable advice.

\section{REFERENCES}

1) Steiner DF, Cunningham D, Spigelman L, et al: Insulin biosynthesis: Evidence of a precursor. Science 157: 697, 1967.

2) Baba S, Sakai H, Yokono K, et al: Insulin degrading enzyme: Its purification, characterization and biological significance. Excerpta Medica ICS 280: 238, 1977.

3) Kitabchi AE, Duckworth WC, Brush JS, et al: Direct measurement of proinsulin in human plasma by the use of an insulin-degrading enzyme. J Clin Invest 50: 1792, 1971.

4) Izzo JL, Roncone A, Izzo MJ: Degradation of ${ }^{131}$ I-insulin by rat liver, kidney and muscle extracts. Fed Proc 30: 193, 1971.

5) Kitabchi AE, Stentz F: Degradation of insulin and proinsulin by various organ homogenates of rat. Diabetes 21: 1091, 1972.

6) Rubenstein AH, Pottenger LA, Mako M, et al: The metabolism of proinsulin and insulin by the liver. J Clin Invest 51: 912, 1972.

7) Stoll RW, Touber JI, Menahan LH, et al: Clearance of porcine insulin, proinsulin and connecting peptide 
by the isolated rat liver. Proc Soc Exp Biol Med 111: 894, 1970.

8) Katz AI, Rubenstein AH: Metabolism of proinsulin, insulin and C-peptide in the rats. J Clin Invest 52: $1113,1973$.

9) Morgan CR, Lazarow A: Immunoassay of insulin two antibody system. Diabetes 12: 115, 1963.

10) Kaneko $T$, Oka H, Munemura $M$, et al: Radioimmunoassay of human proinsulin and C-peptide using synthetic human connecting peptide. Endocrinol Jap 21: $141,1974$.

11) Steiner DF, Oyer PE: The biosynthesis of insulin and probable precursor of insulin by a human islet cell adenoma. Proc Natl Acad Sci 57: 473, 1967.

12) Horwitz DL, Starr JI, Mako ME, et al: Proinsulin, insulin and C-peptide concentrations in human portal and peripheral blood. J Clin Invest 55: 1278, 1975.

13) Mako M, Block M, Starr JI, et al: Proinsulin in chronic renal failure and hepatic failure: A reflection of the liver and kidney in its meabolism. Clin Res 31: 631, 1973.

14) Johnston DG, Alberti KGMM, Faber OK, et al: Hyperinsulinism of hepatic cirrhosis: Diminished degradation or hypersecretion? Lancet 1: 10, 1977.

15) Kaneko $T$, Munemura M, Oka H, et al: Demonstration of C-peptide immunoreactivity in various body fluids and clinical evaluation of the determination of urinary C-peptide immunoreactivity. Endocrinol Jap 22: 207, 1975.

16) Regeur L, Faber OK, Binder C: Plasma C-peptide in uremic patients. Scad J Clin Lab Invest 38: 771, 1978.

17) Jaspan JB, Mako M, Kuzuya H, et al: Abnormalities in circulating beta cell peptides in chronic renal failure: Comparison of C-peptide, proinsulin and insulin. J Clin Endocrinol Metab 45: 441, 1977.
18) Kawai K, Hayakawa H, Yoshida K, et al: Plasma insulin and C-peptide levels in cirrhotic and uremic patients. Diabetes et Metabolism 3: 7, 1977.

19) Gragnoli G, Signorini AM, Tanganell I, et al: Plasma levels of insulin, C-peptide and glucagon in liver cirrhosis. J Endocrinol Invest 4: 1, 1981.

20) Iwasaki $Y$, Ohkubo A, Kajimura H, et al: Degradation and secretion of insulin in hepatic cirrhosis. J Clin Endocrinol Metab 47: 774, 1978.

21) Toccafondi R, Rotella CM, Tanini A, et al: Plasma proinsulin-like components and insulin in chronic liver disease. Hor Metab Res 9: 101, 1977.

22) Kühl C, Faber OK, Hornnes P, et al: C-peptide metabolism and the liver. Diabetes (Suppl. 1) 27: 197, 1978.

23) Mondon CE, Dolkas BC, Reaven GM: Effect of acute uremia on insulin removal by the isolated perfused rat liver and muscle. Metabolism 27: 133, 1978.

24) Rabkin R, Unterhalter SA, Duckworth WC: Effect of prolonged uremia on insulin metabolism by isolated liver and muscle. Kit Int 16: 433, 1979.

25) Starr JI, Juhan DD, Rubenstein AH, et al: Degradation of insulin in serum by insulin-specific protease. J Lab Clin Med 86: 631, 1975.

26) Melani F, Rubenstein AH, Steiner DF: Human serum proinsulin. J Clin Invest 49: 497, 1970.

27) Heding LG: Specific and direct radioimmunoassay for human proinsulin in serum. Diabetologia 13: 467, 1977.

28) Gorden P, Roth J, Hendricks CM, et al: Plasma proinsulin-like components. Isr J Med Sci 10: 1212 , 1974.

29) Cresto JC, Lavine RL, Fink G, et al: Plasma proinsulin: Comparison of insulin specific protease and gel filtration assays. Diabetes 23: 505, 1974. 